\title{
PENINGKATAN KEMAMPUAN KOGNITIF DAN PERILAKU PADA KLIEN DENGAN HARGA DIRI RENDAH MELALUI COGNITIVE BEHAVIOUR THERAPY
}

\author{
Heppi Sasmita ${ }^{1,2 *}$, Budi A. Keliat ${ }^{3}$, Budiharto ${ }^{4}$ \\ 1. Poltekkes Padang, Sumatera Barat 25146, Indonesia \\ 2. Program Studi Magister Fakultas Ilmu Keperawatan Universitas Indonesia, Depok 16424, Indonesia \\ 3. Fakultas Ilmu Keperawatan Universitas Indonesia, Depok 16424, Indonesia \\ 4. Fakultas Kedokteran Gigi Universitas Indonesia, Jakarta 10430, Indonesia \\ *Email: heppi_sasmita@yahoo.co.id
}

\begin{abstract}
Abstrak
Seseorang yang mengalami skizoprenia sering diawali dengan masalah harga diri rendah dengan gejala: konsentrasi dan perhatian kurang, kepercayaan diri kurang, rasa bersalah, tidak berguna, pandangan masa depan yang suram dan pesimistis. Tujuan penelitian ini menilai efektivitas cognitive behaviour therapy $(C B T)$ untuk meningkatkan kemampuan kognitif dan perilaku klien harga diri rendah. Metode penelitian: quasi eksperimen dengan penerapan cognitive behaviour therapy dengan pendekatan pre-post test. Analisis yang digunakan dependen dan independent sample t-Test, regresi linier sederhana, chi-square dan Anova. Penelitian dilakukan di salah satu RS Jiwa terhadap 58 klien yaitu 29 orang kelompok intervensi dan 29 orang kelompok kontrol. Hasil penelitian menunjukkan cognitive behaviour therapy meningkatkan kemampuan kognitif dan perilaku klien skizoprenia dengan harga diri rendah secara bermakna $(\mathrm{p}<0.05, \alpha=0.05)$. Efektifitas $C B T$ meningkatkan kemampuan kognitif sebesar 29,31\% dan kemampuan perilaku sebesar 22,4\%. Penelitian ini merekomendasikan CBT sebagai salah satu terapi spesialis pada klien skizoprenia dengan masalah harga diri rendah.
\end{abstract}

Kata kunci: cognitive behaviour therapy, harga diri rendah, kognitif dan perilaku

\begin{abstract}
Patient with schizophrenia in the beginning is experiencing low self esteem with the following symptoms: concentration difficulty, attention deficit, low self confident, guilty and worthless feelings, and pessimistic. Cognitive behavior therapy is the solutions to enhance cognitive ability as well as to treat behavior of patient with low self esteem. The research aims to study about the effectiveness of cognitive behavior therapy. Method of the research was quasi experiment with pre and post- tests design. The analysis of the research was dependent and independent sample t-test, simple linear regression, chi square, and anova. The research was conducted in mental health hospital with 58 respondents, divided into 29 respondents as intervention group and 29 respondents as control group. The research demonstrated that cognitive behavior therapy has significantly enhanced cognitive ability and treated behavior of patient with low self esteem ( $p<$ $0.05, \alpha=0.05$ ). The research shown the effectiveness to enhance cognitive ability about 29.31 percent, while the effectiveness to treat behavior about 22.4 percent. This study recommended cognitive behavior therapy as specialty treatment for patient schizophrenia with low self esteem.
\end{abstract}

Keyword: behavior, cognitive, cognitive behavior therapy, low self esteem

\section{Pendahuluan}

Gangguan jiwa menurut The American Psychiatric Association's (Shives, 1998) adalah "gangguan psikologis atau manifestasi perilaku dan atau kerusakan fungsi sosial, psikologik, genetik, fisik atau gangguan biologik". Menurut Townsend (2003) gangguan jiwa merupakan respon maladaptif terhadap stressor dari dalam atau luar lingkungan, yang berhubungan dengan perasaan dan perilaku yang tidak sejalan dengan budaya/kebiasaan/normal setempat dan mempengaruhi interaksi sosial individu, kegiatan dan atau fungsi tubuh. Di Indonesia diperkirakan $1-2 \%$ penduduk atau sekitar dua sampai empat juta jiwa terkena gangguan jiwa. Survei tentang penderita gangguan jiwa tercatat 44,6 per 1.000 penduduk menderita gangguan jiwa berat seperti skizofrenia.

Seseorang yang mengalami skizoprenia diawali dengan masalah harga diri rendah dengan gejala: konsentrasi dan perhatian kurang, kepercayaan diri kurang, rasa bersalah, tidak berguna, pandangan masa depan yang suram dan pesimistis.

Saat ini asuhan keperawatan dengan masalah harga diri rendah pada klien skizoprenia belum optimal, sehingga kognitif dan perilaku klien masih negatif. 
Terapi individu yang sudah dikembangkan pada klien skizoprenia tersebut adalah cognitive behaviour therapy (Turkington, 2002).

Cognitive behaviour therapy bertujuan untuk mengajak klien menentang kognitif, perilaku dan emosi yang salah dengan menampilkan bukti-bukti yang bertentangan dengan keyakinan mereka tentang masalah yang dihadapi (Wikipedia, 2007).

Peneliti ingin mengetahui lebih jauh mengenai efektivitas cognitive behaviour therapy dalam mengubah kognitif dan perilaku negatif klien yang mengalami masalah harga diri rendah.

\section{Metode}

Penelitian inimenggunakan desain kuasi-eksperimen, dengan rancangan Quasi experimental pre-post test control group. Pemilihan sampel menggunakan simple random sampling. Penelitian dilakukan di salah satu RS Jiwa, selama 6 minggu (25 April-8 Juni 2007).

Sampel dipilih dengan kriteria inklusi: 1) Usia 18 55 tahun, 2) Jenis kelamin: pria dan wanita, 3) Pendidikan: SD sampai perguruan tinggi, 4) Pekerjaan: bekerja dan tidak bekerja, 5) Status perkawinan: menikah dan belum menikah, 6) Klien dirawat di salah satu RS Jiwa, 7) Diagnosa medis: Skizoprenia. Berdasarkan kriterian inklusi tersebut maka didapatkan 58 pasien, dengan perincian 29 pasien kelompok intervensi dan 29 pasien kelompok kontrol.

Hasil pengisian kuesioner digunakan sebagai data pretes. Kemudian klien yang diintervensi disamping mendapat asuhan keperawatan dari ruangan ditambah dengan intervensi cognitive behaviour therapy oleh peneliti. Cognitive behaviour therapy dilakukan selama lima minggu yang terdiri dari lima sesi dan satu kali sesi dilakukan dua kali.

Dalam penelitian ini cognitive behaviour therapy dilakukan dalam lima sesi yaitu, Sesi 1: Mengungkapkan perasaan, pikiran otomatis yang negatif tentang diri sendiri, orang lain dan lingkungan yang dialami klien (assessment) dan mengenali pikiran dan perilaku negatif yang dialami. Sesi 2 : Belajar cara untuk mengatasi pikiran negatif, Sesi 3:
Menyusun rencana perilaku dengan memberikan konsekwensi positif-konsekwensi negatif, Sesi 4: Mengevaluasi kemajuan dan perkembangan terapi, menfokuskan terapi, dan mengevaluasi perilaku yang dipelajari berdasarkan konsekwensi yang disepakati, Sesi 5: Menjelaskan pentingnya psikofarmaka dan terapi modalitas lainnya untuk mencegah kekambuhan dan mempertahankan pikiran positif dan perilaku adaptif secara mandiri dan berkesinambungan.Sedangkan pada kelompok kontrol hanya diberikan asuhan keperawatan sesuai standar ruangan. Pengukuran kemampuan kognitif dan perilaku dilakukan sama dengan kelompok intervensi.

Pelaksanaan CBT tersebut contohnya: klien dengan perasaan negatif merasa dirinya bodoh sehingga tidak mau bergaul dengan orang lain. Pada klien tersebut dianjurkan untuk berfikir positif bahwa dirinya sebenarnya tidak bodoh karena masih banyak yang dapat dilakukan klien. Kemudian klien di anjurkan untuk mengungkapkan hal positif yang sudah dilakukan selama ini.

Selanjutnya klien disuruh merencanakan perilaku positif yang akan dilakukan seperti bergaul dengan orang lain, tidak mudah marah pada orang lain. Kemudian klien dianjurkan membuat konsekwensi, jika perilaku positif ditampilkan apa hadiahnya, tapi jika perilaku positif tidak ditampilkan apa hukumannya bagi klien.

\section{Hasil}

\section{Karakteristik Klien}

Karakteristik klien harga diri rendah rata-rata berusia 26 - 55 tahun, jenis kelamin pada umumnya lakilaki, bekerja dan status perkawinan lebih dari sebagian tidak kawin. Rata-rata kognitif sebelum intervensi pada kelompok intervensi lebih rendah dari kelompok kontrol.

Hasil uji Kolmogorov Smirnov menunjukkan distribusi kemampuan kognitif berbentuk normal, dimana pada kelompok intervensi ( $p>0,05, \alpha=$ $0,05)$ dan kelompok kontrol ( $p>0,05, \alpha=0,05)$. Rata-rata kemampuan perilaku sebelum intervensi pada kelompok kontrol lebih rendah dari kelompok intervensi. 
Tabel 1. Analisis Peningkatan Kemampuan Kognitif dan Perilaku Klien Harga Diri Rendah Sebelum - Sesudah Cognitive Behaviour Therapy

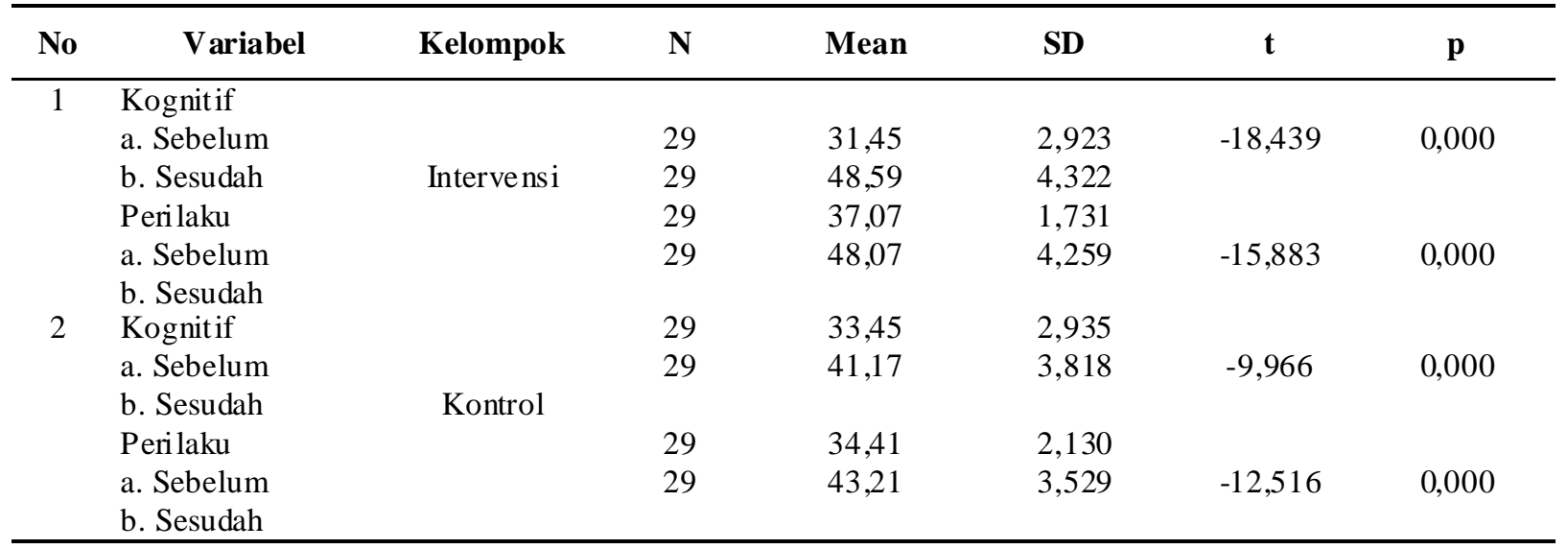

Hasil uji Kolmogorov Smirnov menunjukkan distribusi kemampuan perilaku berbentuk normal, dimana pada kelompok intervensi ( $\mathrm{p}>0,05, \alpha=$ $0,05)$ dan kelompok kontrol ( $p>0,05, \alpha=0,05)$. Rata-rata kemampuan kognitif sesudah intervensi pada kelompok intervensi lebih tinggi dari kelompok kontrol. Rata-rata kemampuan perilaku sesudah intervensi pada kelompok intervensi lebih tinggi dari kelompok kontrol.

\section{Peningkatan Kemampuan Kognitif dan Perilaku Klien Harga Diri Rendah Sebelum - Sesudah Intervensi pada Kelompok Intervensi dan Kontrol}

Uji statistik yang dilakukan adalah melakukan uji dependen sample t-Test (Paired t test) (lihat tabel 1). Rata-rata peningkatan antara kemampuan kognitif klien harga diri rendah sebelum dan sesudah mendapatkan cognitive behaviour therapy pada kelompok intervensi adalah sebesar 17.

Rata-rata peningkatan antara kemampuan perilaku klien harga diri rendah sebelum dan sesudah mendapatkan adalah sebesar 13. Nilai rata-rata peningkatan antara kemampuan kognitif klien harga diri rendah sebelum dan sesudah intervensi pada kelompok kontrol adalah sebesar 7,72 dengan standar deviasi 3,818.

Hasil uji statistik yang didapatkan menunjukkan bahwa ada peningkatan yang signifikan antara kemampuan kognitif klien harga diri rendah berdasarkan sebelum dan sesudah intervensi cognitive behaviour therapy pada kelompok kontrol ( $p<0,05, \alpha=0,05)$. Rata-rata peningkatan antara kemampuan perilaku klien harga diri rendah sebelum dan sesudah intervensi pada kelompok kontrol adalah sebesar 8,8 dengan standar deviasi 3,529 .

Hasil uji statistik didapatkan ada peningkatan yang signifikan antara kemampuan perilaku klien harga diri rendah sebelum dan sesudah intervensi cognitive behaviour therapy pada kelompok kontrol $(\mathrm{p}<$ $0,05, \alpha=0,05)$. Format evaluasi proses CBT yang sudah dikembangkan (terlampir dalam modul CBT).

\section{Peningkatan Kemampuan Kognitif dan Perilaku Klien Yang Mendapatkan Cognitive Behaviour Therapy dan Yang Tidak Mendapatkan Cognitive Behaviour Therapy}

a melihat peningkatan kemampuan klien sebelum dan sesudah dilakukan CBT dengan menggunakan uji dependen sample t-Test (Paired t test). Sedangkan b melihat peningkatan kemampuan klien yang mendapat CBT dan yang tidak dengan menggunakan uji independen sample t-Test (Pooled t test). Uji statistik yang dilakukan adalah melakukan uji independen sample t-Test (Pooled t test) (lihat tabel 2).

Rata-rata kemampuan kognitif pada klien harga diri rendah yang mendapatkan CBT lebih tinggi 7,42 dibanding klien yang tidak mendapatkan terapi. Hasil uji statistik menunjukkan kemampuan kognitif klien harga diri rendah kelompok intervensi meningkat secara bermakna dengan kelompok kontrol $(\mathrm{p}<$ $0,05, \alpha=0,05)$. 
Tabel 2. Analisis Peningkatan Kemampuan Kognitif dan Perilaku Klien yang Mendapatkan CBT dan yang Tidak Mendapatkan CBT

\begin{tabular}{cllccccc}
\hline No & Kelompok & \multicolumn{1}{c}{ Variabel } & Mean & SD & N & t & p \\
\hline 1 & Intervensi & Kognitif sebelum & 31,45 & 2,923 & 29 & $-2,600$ & 0,012 \\
& Kontrol & intervensi & 33,45 & 2,935 & 29 & & \\
2 & Intervensi & Kognitif sesudah & 48,59 & 4,322 & 29 & 6,923 & 0,000 \\
& Kontrol & intervensi & 41,17 & 3,818 & 29 & & \\
\multirow{2}{*}{3} & Intervensi & Perilaku sebelum & 35,07 & 1,731 & 29 & 1,286 & 0,204 \\
& Kontrol & intervensi & 34,41 & 2,130 & 29 & & \\
\multirow{2}{*}{4} & Intervensi & Perilaku sesudah & 48,07 & 4,259 & 29 & 4,734 & 0,000 \\
& Kontrol & intervensi & 43,21 & 3,529 & 29 & & \\
\hline
\end{tabular}

Rata-rata kemampuan perilaku klien harga diri rendah pada klien yang mendapatkan cognitive behaviour therapy lebih tinggi 4,86 dibandingkan klien yang tidak mendapatkan cognitive behaviour therapy. Hasil uji statistik didapatkan kemampuan perilaku klien harga diri rendah kelompok intervensi meningkat secara bermakna dengan kelompok $\operatorname{kontrol}(\mathrm{p}<0,05, \alpha=0,05)$.

\section{Hubungan karakteristik klien dengam peningkatan kemampuan kognitif dan perilaku}

Cognitive behaviour therapy yang dilakukan, menunjukkan hanya pendidikan yang berhubungan secara bermakna dalam peningkatan kemampuan kognitif klien harga diri rendah pada klien yang mendapatkan cognitive behaviour therapy.

\section{Pembahasan}

Cognitive behaviour therapy meningkatkan secara bermakna kemampuan kognitif dan perilaku klien harga diri rendah pada klien yang mendapatkan cognitive behaviour therapy. Masalah harga diri rendah pada klien skizoprenia sering ditemui dengan gejala penurunan kemampuan kognitif.

Teori Fluid and Crystallized Intelligence dari Catell dan Horn (1982, dalam Miller, 1995) telah digunakan untuk menjelaskan penurunan beberapa kemampuan kognitif. Crystallized Intelligence merujuk pada keterampilan kognitif yang didapatkan melalui budaya, pendidikan, pembelajaran informal, dan pengalaman hidup lainnya. Selain itu, faktor yang berkontribusi dengan penurunan kemampuan kognitif adalah neuroanatomic, psikologis, lingkungan dan faktor lain dan kejadian (Laeckenote, 1996).
Cognitive behaviour therapy yang dilakukan berorientasi pada kegiatan dalam merubah kognitif yang negatif dan perilaku yang maladaptif menjadi kognitif yang positif dan perilaku yang adaptif. Sullivan, et.al, 2003 menjelaskan bahwa cognitive behaviour therapy merupakan pengobatan dengan pendekatan terhadap konsep dasar jalan pikiran dan bagaimana meresponnya.

Hasil penelitian membuktikan bahwa CBT efektif dalam meningkatkan kemampuan kognitifklien harga diri rendah yang mengikuti CBT dibandingkan klien harga dirirendah yang tidak mengikuti CBT. Hal ini disebabkan karena CBT merupakan salah satu psikoterapi yang dapat meningkatkan harga diri klien skizoprenia.

Perbedaan peningkatan kemampuan kognitif antara klien yang mendapatkan cognitive behaviour therapy dan yang tidak mendapatkan cognitive behaviour therapy tidak terlalu tinggi, namun cukup bermakna dalam meningkatkan harga diri khususnya pada klien skizoprenia. Kondisi ini disebabkan karena pelaksanaan cognitive behaviour therapy hanya dilakukan sesuai perencanaan selama 5 minggu sehingga hasil yang diperoleh belum mencapai nilai optimal.

Penjelasan diatas memperlihatkan bahwa cognitive behaviour therapy belum mencapai hasil optimal, kemungkinan juga disebabkan kerusakan kemampuan kognitif dipengaruhi oleh keseimbangan neurotransmiter diotak. Pendapat ini didukung Stuart dan Laraia (2005) yang mengatakan terganggunya kerja hormon secara umum, dapat pula berdampak pada keseimbangan neurotransmitter di otak. 
Contohnya kadar serotonin yang menurun dapat mengakibatkan klien mengalami depresi dan pada pasien depresi kecenderungan harga diri rendah kronis semakin besar karena klien dikuasai oleh pikiran-pikiran negatif dan merasa tidak berdaya.

Cognitive behaviour therapy meningkatkan secara bermakna kemampuan perilaku klien harga diri rendah yang mendapatkan cognitive behaviour therapy. Hasil penelitian membuktikan bahwa cognitive behaviour therapy efektif dalam meningkatkan kemampuan kognitif klien harga diri rendah yang mengikuti cognitive behaviour therapy. Hal ini disebabkan karena cognitive behaviour therapy merupakan salah satu psikoterapi yang dapat meningkatkan harga diri klien skizoprenia.

Perbedaan peningkatan kemampuan kognitif antara yang mendapatkan cognitive behaviour therapy dan yang tidak mendapatkan cognitive behaviour therapy dalam penelitian tidak terlalu tinggi, namun cukup bermakna dalam meningkatkan harga diri khususnya pada klien skizoprenia. Hal ini disebabkan karena mengingat pelaksanaan cognitive behaviour therapy hanya dilakukan sesuai perencanaan selama 5 minggu sehingga hasil yang diperoleh belum mencapai nilai optimal.

Hasil evaluasi pelaksanaan cognitive behaviour therapy yang dilakukan selama 5 minggu, menunjukkan peningkatan kemampuan kognitif yang cukup bermakna. Apabila waktu penelitian dipersiapkan cukup lama, tentu klien akan mencapai kemampuan kognitif yang lebih optimal. Hal ini menunjukkan keefektifan cognitive behaviour therapy yang dilakukan dalam mengatasi masalah harga diri rendah pada klien skizoprenia.

Pendapat ini didukung Turkington (2002) yang mengatakan bahwa pada klien skizoprenia, cognitive behaviour therapy juga menunjukkan hasil yang cukup memuaskan. Dimana teknik yang digunakan berorientasi pada masalah dan tugas dalam mengubah kognitif yang salah atau bias (menggunakan kognitif dan pandangan) dengan menilai situasi dan memodifikasi asumsi.

Hasil penelitian membuktikan bahwa cognitive behaviour therapy efektif dalam meningkatkan kemampuan kognitif klien harga diri rendah yang mengikuti cognitive behaviour therapy dibandingkan klien harga diri rendah yang tidak mengikuti cognitive behaviour therapy. Hal ini disebabkan karena cognitive behaviour therapy merupakan salah satu psikoterapi yang dapat meningkatkan harga diri klien skizoprenia.

Perbedaan peningkatan kemampuan kognitif antara klien yang mendapatkan cognitive behaviour therapy dan yang tidak mendapatkan cognitive behaviour therapy dalam penelitian tidak terlalu tinggi, namun cukup bermakna dalam meningkatkan harga diri khususnya pada klien skizoprenia.

Cognitive behaviour therapy yang dilakukan, menunjukkan hanya pendidikan yang berhubungan secara bermakna dalam peningkatan kemampuan kognitif klien harga diri rendah pada klien yang mendapatkan cognitive behaviour therapy. Hal ini didukung pendapat Reasoner (2007), adanya hubungan yang erat antara harga diri dengan pencapaian akademik.

Meningkatnya rata-rata harga diri berdasarkan kemampuan kognitif dan perilaku ini pada klien yang mendapatkan cognitive behaviour therapy. Hal ini disebabkan karena selama pelaksanaan intervensi cognitive behaviour therapy klien diberi informasi dan dilatih merubah pikiran negatif menjadi positif dan perilaku menjadi adaptif.

\section{Kesimpulan}

CBT meningkatkan secara bermakna kemampuan kognitif dan perilaku klien harga diri rendah. Kemampuan kognitif dan perilaku klien yang mendapat CBT lebih tinggi secara bermakna dari klien yang tidak mendapatkan CBT. Pendidikan berhubungan secara bermakna terhadap peningkatan kemampuan kognitif dan perilaku klien harga diri rendah yang mendapatkan cognitif behavior therapy (HW, BK, TN).

\section{Referensi}

Leuckenote. (1996). Pengkajian gerontologi. Jakarta: EGC.

Miller, A.C. (1995). Nursing care of older adult, theori and practice (2nd Edition). Philadelphia: W.B. Saunders Company. 
Reasoner, R.W. (2007). Revieu of self esteem research. Diperoleh dari http://www.selfesteem-internasional.org.

Shives, L.R. (1998). Basic concepts of psychiatricmental health nursing (4th Editin). Philadelphia: Lippincott.

Stuart, G..W., \& Laraia, M.T. (2005). Principles and practice of psychiatric nursing (8th Edition). Philadelphia: Elsevier Mosby.

Sullivan, et. al. (2003). Cognitive behaviour therapy. Diperoleh dari http:// www.health.qld.gov.au/rbwh/inbmhs/factsheets/ cbt.pdf.
Turkington, D \& Kingdon, G.(2002). The case study guide to cognitive behaviour therapy of psychosis. England: John Wiley \& Sons, ltd.

Wikipedia. (2007). Cognitive behaviour therapy. Diperoleh dari http://en.wikipedia.org/wiki/ cognitive_behaviour_therapy.

Bila Anda berpikir Anda bisa, maka Anda benar.

Bila Anda berpikir Anda tidak bisa, Anda pun benar.

Karena itu ketika seseorang berpikir tidak bisa, maka sesungguhnya dia telah membuang kesempatan untuk menjadi bisa - Henry Ford -

Konsentrasikan pikiran Anda pada sesuatu yang Anda lakukan, karena sinar matahari juga tidak dapat membakar sebelum difokuskan - Alexander Graham Bell -

Jika Anda ingin berbahagia selama satu jam, silakan tidur siang. Jika Anda ingin berbahagia selama satu hari, pergilah berpiknik. Bila Anda ingin berbahagia seminggu, pergilah berlibur.

Bila Anda ingin berbahagia selama sebulan, menikahlah.

Bila Anda ingin berbahagia selama setahun, warisilah kekayaan.

Jika Anda ingin berbahagia seumur hidup, cintailah pekerjaan Anda

- Promod Brata -

Orang yang paling beruntung di dunia adalah orang yang telah mengembangkan rasa syukur yang hampir konstan, dalam situasi apapun

- E. Nightingale - 